\section{Accepted Manuscript}

the Conference on Control Applications was held in Glasgow, Scotland, UK, September 18-20, 2002 jointly the 12th IEEE International Symposium on Computer Aided Control System Design.

Multi-cell chopper direct control law preserving optimal limit cycles

Olivier Béthoux, Jean-Pierre Barbot

DOI:

doi: $10.1109 /$ CCA.2002.1038786

Reference:

International Conference on Control Applications, Glasgow, 2002

Publisher:

IEEE

To appear in:

IEEE Conferences

Conference date:

18-20 Sept. 2002

Date of Publication: 10 December 2002 (available on line)

Please cite this article as:

O. Bethoux and J. P. Barbot, "Multi-cell chopper direct control law preserving optimal limit cycles", Proceedings of the International Conference on Control Applications, Glasgow, UK, 2002, pp. 1258-1263 vol.2.

doi: 10.1109/CCA.2002.1038786

URL:

http://ieeexplore.ieee.org/stamp/stamp.jsp?tp=\&arnumber=1038786\&isnumber=22259URL

Document Version: $\quad$ Early version, also known as pre-print

This is a PDF file of an unedited manuscript that has been accepted for publication. As a service to our customers we are providing this early version of the manuscript. The manuscript will undergo copyediting, typesetting, and review of the resulting proof before it is published in its final form. Please note that during the production process errors may be discovered which could affect the content, and all legal disclaimers that apply to the journal pertain. 


\title{
Multi-cell chopper direct control law preserving optimal limit cycles
}

\author{
OLIVIER BETHOUX ${ }^{1}$, JEAN-PIERRE BARBOT $^{1}$ \\ ${ }^{1}$ Equipe Commande des Systèmes (ECS), ENSEA \\ 6, avenue du Ponceau, 95014 Cergy-Pontoise Cedex , France \\ bethoux@ensea.fr, barbot@ensea.fr \\ http://www.ensea.fr
}

\begin{abstract}
Series multi-cell converters provide many degrees of freedom. Direct control laws make perfect use of them during transient behaviours but leads to disorderly and imperfect steady-state cycles [4]. The direct command, we propose in this paper, enables the multi-cell converter to reach the optimal steady-state trajectory defined by a P.W.M. control technique. As usual, this control strategy enforce naturally high dynamic properties. Thus, it combines the best features of PWM techniques and direct control strategies.

Moreover, this control scheme only needs external variables measurement (input voltage and output current). For the sake of simplicity, the control algorithm, the observer structure as well as the association of both of them are described carefully in the case of a two-cell chopper.
\end{abstract}

Keywords - Multi-cell converters, sliding modes, hybrid system, control command, state observation.

\section{INTRODUCTION}

Limited by power switches voltage and current features available at present time, the power converter designer often needs to associate power switches to reach a set of requirements. In order to deal with high current levels, he considers parallel association of them. As far as high voltage levels are concerned, he considers series association of them. The latter association is full of interest because semiconductor components are the more effective since their voltage characteristics are low.

The series multi-cell converter designed by the LEEI (Toulouse - France) [1], [2] leads to a safe series association of components working in switching mode. This new structure combines two additional benefits : standardized designs and use of common use components.

All these qualities make this new topology very attractive to many manufacturers. Consequently, the applications of it are numerous. For instance, GEC/ACEC implements this proposal to realize the input chopper which supply their "T13" locomotives in power. Three-phase inverters called "Symphony" and developed by Alstom to drive electric motors are also based on the same principle.

Until now, all these multi-cell power converters are driven, with success, by the mean of a fix frequency modulator based on pulsed width modulation (P.W.M.). Current control algorithms do not take into account the fact that any power converter is a discrete and discontinuous plant, or, at least a hybrid one. Nevertheless, the profitable skill of P.W.M. technique is to ensure a well-known steady state behaviour which is optimal for the electric load. As a drawback, the control algorithm is compelled to poor dynamic properties so as to respect the average model on which it is based.
Several papers [9], [10], [11] have demonstrated that series multi-cell converters increase reliability of power systems. As a matter of fact, short circuit is the most common failure on power switches and this fault localized in this kind of structure ? Moreover, in this particular case, a N-cell converter can be reorganized as a $(\mathrm{N}-1)$-cell converter : it is also possible to isolate this failure. So, the reliability of the power system may be enhanced if using $(\mathrm{P}+\mathrm{M})$ cells where $\mathrm{P}$ is the minimum number of cells necessary to meet a given requirement and $\mathrm{M}$ is a number of additional modules which give the system the ability to tolerate $\mathrm{M}$ failures without impact. However, to ensure good reliability, the power system needs fast response. The cell voltages of the detected $(\mathrm{N}-1)$ safe cells must converge as quick as possible to the new reference value $\left(\frac{\mathrm{VE}}{\mathrm{N}-1}\right)$ in order to avoid any destructive transient over voltage.

This is why we propose both a high band width state observer as well as a high speed control law (regarding the intrinsic system abilities).

The purpose of the present article is to propose a direct control algorithm [13] (without modulator) preserving optimal limit cycles (and hence harmonic properties) which only needs external sensors : input voltage sensor and output current sensor.

This article is divided into three parts. The first section describes the control law. The second section details the observer structure. The last section underlines the interaction between both blocks. At each steps, relevant simulations illustrate the main issues.

\section{DIRECT CONTROL LAW}

\section{A. Multi-cell Converter Model}

The multi-cell converter connects $\mathrm{N}$ elementary cells in series. Figure 1 describes this structure in the case of a two-cell chopper connected to a passive load R and L. Each switching cell is controlled by a binary $\mathrm{u}_{\mathrm{k}}(\mathrm{t})$.

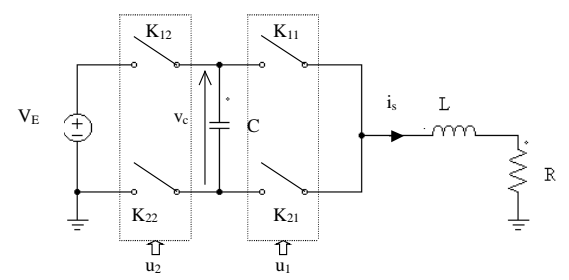

We denote :

Figure 1 two-cell chopper

$$
\begin{array}{lll}
\mathrm{u}_{\mathrm{k}}=1 & \Leftrightarrow & \left(\mathrm{K}_{\mathrm{k} 1} \text { closed } ; \mathrm{K}_{\mathrm{k} 2} \text { open }\right) \\
\mathrm{u}_{\mathrm{k}}=0 & \Leftrightarrow & \left(\mathrm{K}_{\mathrm{k} 1} \text { open } ; \mathrm{K}_{\mathrm{k} 2} \text { closed }\right)
\end{array}
$$


With the above notations, this system is described by the two following equations :

$$
\begin{aligned}
& \left(\text { Eq 1) } \frac{\mathrm{dv}_{\mathrm{c}}}{\mathrm{dt}}=\frac{\left[\mathrm{u}_{2}(\mathrm{t})-\mathrm{u}_{1}(\mathrm{t})\right]}{\mathrm{C}} \mathrm{is}_{\mathrm{s}}(\mathrm{t})\right. \\
& \left(\text { Eq 2) } \frac{\mathrm{dis}}{\mathrm{dt}}=-\frac{\left[\mathrm{u}_{2}(\mathrm{t})-\mathrm{u}_{1}(\mathrm{t})\right]}{\mathrm{L}} \mathrm{vc}_{\mathrm{c}}(\mathrm{t})-\frac{\mathrm{R}}{\mathrm{L}} \mathrm{i}_{\mathrm{s}}(\mathrm{t})+\frac{\mathrm{u}_{2}(\mathrm{t})}{\mathrm{L}} \mathrm{V}_{\mathrm{E}}\right.
\end{aligned}
$$

In one hand, the control law aims at closely tracking the output current reference $\left(i_{s}\right)_{\text {reff }}(t)$ and, on the other hand, it aims at keeping the internal voltage at its optimal value $\frac{\mathrm{VE}}{2}$.

\section{B. Structure controllability}

Controllability is quite an essential issue since we wonder whether, thanks to the control variable, the control law will be able to make the power supply reach any given state. Consequently, we ask us the following question: "Being at state $X$, may I put the system to the narrow state $X+\Delta X$ ?"(note) By rewriting equations $(\mathrm{Eq} 1)$ and $(\mathrm{Eq} 2)$ in a state space equation which is affine with respect to the control variable (Eq 3), we get :

$$
\frac{\mathrm{dX}}{\mathrm{dt}}=\mathrm{F}(\mathrm{X})+\mathrm{G}(\mathrm{X}) \mathrm{U}
$$

where

$$
\mathrm{X}=\left\lfloor\begin{array}{l}
\mathrm{yc} \\
\mathrm{is}
\end{array}\right\rfloor, \quad \mathrm{U}=\left[\begin{array}{l}
\mathrm{u} 1 \\
\mathrm{u} 2
\end{array}\right], \quad \mathrm{F}(\mathrm{X})=\left[\begin{array}{cc}
0 & 0 \\
0 & -\frac{\mathrm{R}}{\mathrm{L}} \text { is }
\end{array}\right]
$$

$$
G(X)=\left[\begin{array}{cc}
-\frac{i s}{C} & +\frac{i s}{C} \\
\frac{v c}{L} & \frac{V E-v c}{L}
\end{array}\right]
$$

with :

$$
\text { (Eq 4) } \operatorname{det}(\mathrm{G})=-\frac{\mathrm{V}_{\mathrm{E}} \mathrm{i}_{\mathrm{s}}}{\mathrm{LC}}
$$

We hence deduce that, for a continuous and unbounded control variable $\mathrm{U}(\mathrm{t})$, a sufficient controllability condition is :

$$
\operatorname{det}(\mathrm{G}) \neq 0 \text {. }
$$

Which means that, in order to avoid any controllability problem, we must avoid the singular straight line : $\mathrm{D}=\left\{X: \mathrm{i}_{\mathrm{s}}=0\right\}$.

As a matter of fact, if the load does not take any current from the chopper, equation (Eq 1) shows that the control variable cannot influence the internal voltage value $\mathrm{v}_{\mathrm{c}}(\mathrm{t})$. In this particular case, the state component able to modify the system state is current $i_{s}(t)$, variable of energy transfer. In $\S$ II.D we prose a strategy to overcome this singularity.

We also notice another remarkable case : when parameter $V_{E}$ is equal to zero, the system loose controllability. This second case however can be treated as a start procedure.

This first analysis is quite instructive but does not actually answer to the initial question : the seek of a necessary and sufficient controllability condition in the case of our converter, which means in the case of a discrete actuator. The control

${ }^{\text {(note) }}$ As our study is local, we have:

$e^{h L_{F} u_{2}} e^{h L_{F} u_{1}}=e^{h L_{F} u_{1}} e^{h L_{F} u_{2}}$

and hence, in the neighbourhood of $\mathrm{X}_{0}$ the controllability subspace is given by

$\operatorname{span}\left\{F(X)+G(X) U_{k}\right\}_{X}=X_{0}$

For a global study, the controllability subspace is spanned by the union of the different subspaces generated by each vector $\frac{\mathrm{dX}}{\mathrm{dt}}\left(\mathrm{U}_{\mathrm{k}}\right)$. It results a difficult convex problem which is not relevant since we intend to stabilize the trajectory around an equilibrium point. variable $U(t)$ is in fact a discrete variable with $2^{2}$ different values. Moreover, we cannot apply a particular value of $U$ during a negative length of time !

That is why a question which sounds more relevant is : "If the system is at state $X$, and, as I want it to reach the narrow state $\mathrm{X}+\Delta \mathrm{X}$, shall $\mathrm{I}$ find a set of length of time $\left[\delta \mathrm{t}_{1} \delta \mathrm{t}_{2} \ldots \delta \mathrm{t}_{\mathrm{p}}\right]$ associated to $\mathrm{p}$ control values $\mathrm{U}_{1} \ldots \mathrm{U}_{\mathrm{p}}$ such as :

$$
\sum_{\mathrm{k}=1}^{\mathrm{p}} \delta \mathrm{tk} \frac{\mathrm{dX}}{\mathrm{dt}}(\mathrm{Uk})=\Delta \mathrm{X}
$$

and satisfying the $\mathrm{p}$ constraints : $\delta \mathrm{t}_{\mathrm{k}} \geq 0$ ?"

We intend to answer this question by analysing all the directions provided by the different command values ( $\$$ II.C). Afterwards, we shall propose a direct control law based on a geometric approach.

\section{State changes generated by the $2^{2}$ different control values}

In a first step, we observe, in the phase portrait $\left(i_{s} ; v_{c}\right)$ the action on $\mathrm{X}$ generated by the use of each possible converter configuration. The four discrete command values $\mathrm{U}(\mathrm{k})=\left[\begin{array}{l}\mathrm{u} 1(\mathrm{k}) \\ \mathrm{u} 2(\mathrm{k})\end{array}\right]$ are numbered according to Gray code in order to put in a prominent position adjacent control values (or, to put it another way control values which differ only from one switching cell state). This concept is essential as far as it is important to minimize the number of switching : hence, one can reach thermal constraint. $\mathrm{U}(\mathrm{k})=\left[\begin{array}{l}\mathrm{u} 1(\mathrm{k}) \\ \mathrm{u} 2(\mathrm{k})\end{array}\right]$.

The following chart gives the arbitrary numeration we adopted.

\begin{tabular}{|c|c|c|}
\hline \multirow{2}{*}{$\begin{array}{c}\text { Control variable } \\
\text { number }\end{array}$} & $\mathrm{u}_{2}(\mathrm{k})$ & $\mathrm{u}_{1}(\mathrm{k})$ \\
\cline { 2 - 3 } & 0 & 0 \\
\hline 0 & 0 & 1 \\
\hline 1 & 1 & 1 \\
\hline 3 & 1 & 0 \\
\hline
\end{tabular}

By adding or subtracting one (modulo4), we commute from one control value to another by a unique commutation.

Equation (Eq 1) underlines that $\mathrm{U}_{0}$ and $\mathrm{U}_{2}$ only act on the $\mathrm{Y}$ axis. . we denote these two control values $U_{\text {is. }}$.

On the other hand, $U_{1}$ and $U_{3}$ act on, in a symmetric way, on $\mathrm{X}$-axis ; this action is all the more effective since output current value $i_{s}(t)$ is great $(E q 2)$.

Figures 2-a , 2-b et 2-c illustrate these developments in the case of a positive output current $i_{\mathrm{s}} \geq 0$.
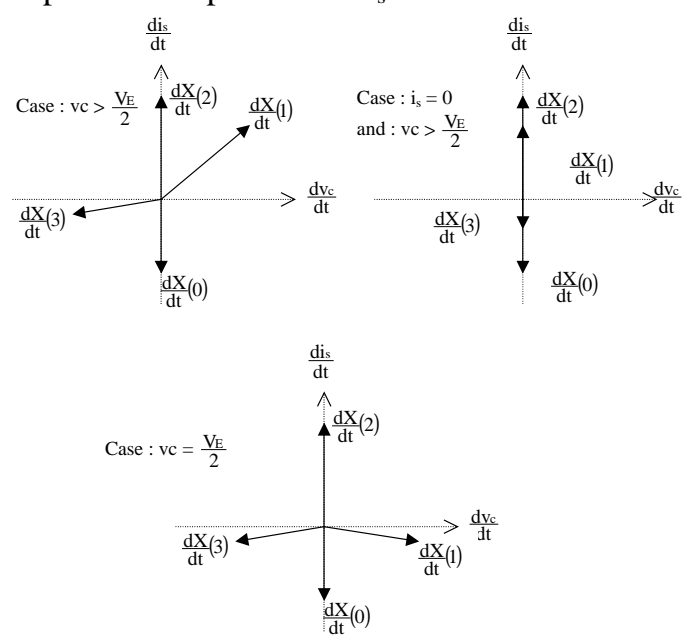

Figure 2 : actions yielded by the 4 control values 
This study allows us to conclude the controllability of the structure in all the state, except along the singular straight line D.

\section{Principle of the control algorithm}

It sounds us important to recall that power electronics systems should better work with a fixed frequency in order to overcome thermal aspects as well as harmonics generated in steady state. Our control issue can be formulated as the following question: "How can we go from one point in the phase portrait $\left(\mathrm{v}_{\mathrm{c}} ; \mathrm{i}_{\mathrm{s}}\right)$ to another with the constraint of a constant length of time?"

In order to solve this 3-dimensional problem (state and time) we need at least three different control values. In steady state, the trajectory must be closed. During transient behaviours, it does not make sense going one way and then the opposite way. These remarks lead us to choose between two different control values sets $\left[\mathrm{U}_{1} \mathrm{U}_{\mathrm{is}} \mathrm{U}_{3}\right]$. We make the choice by solving equations (Eq 5) et (Eq 6) :

(Eq 5) $\delta t_{1} \frac{d X}{d t}\left(U_{1}\right)+\delta t_{\text {is }} \frac{d X}{d t}\left(U_{\text {is }}\right)+\delta t_{3} \frac{d X}{d t}\left(U_{3}\right)=X_{\text {réf }}-X$

$\left(\right.$ Eq 6) $\delta \mathrm{t}_{1}+\delta \mathrm{t}_{\text {is }}+\delta \mathrm{t}_{3}=\mathrm{TD}$

with the three constraints: $\delta \mathrm{t}_{1} \geq 0, \delta \mathrm{t}_{\mathrm{is}} \geq 0, \delta \mathrm{t}_{3} \geq 0$.

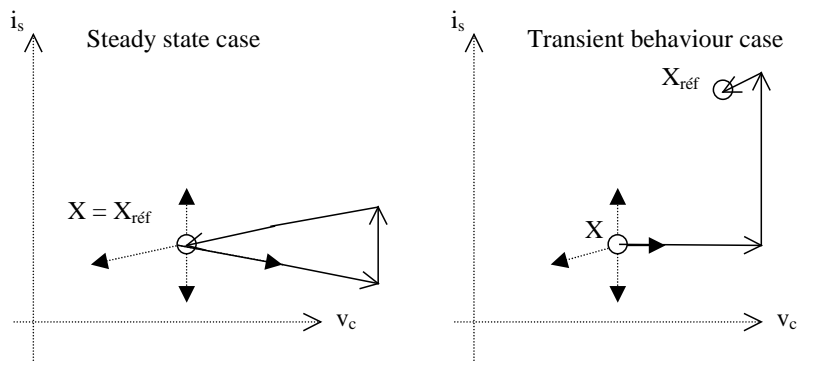

Figure 3 : Solution to (Eq 5) et (Eq 6) with $\delta t_{k} \geq 0$

In order to commutate from a control value to an adjacent control value, we have to apply first $\mathrm{U}_{1}, \mathrm{U}_{\text {is }}$ and finally $\mathrm{U}_{3}$ or $\mathrm{U}_{3}, \mathrm{U}_{\mathrm{is}}$ and $\mathrm{U}_{1}$. Following the same idea (minimizing the number of commutations), we have to apply $\left[\mathrm{U}_{1} \mathrm{U}_{\mathrm{is}} \mathrm{U}_{3}\right]$ after the use of $\left[U_{3} \quad U_{\text {is }} U_{1}\right]$ and vice versa. In steady state, the trajectory yielded by this method is the same as the one generated by a P.W.M. modulator.

By solving equations (Eq 5) et (Eq 6), one can get sets $\left[\delta t_{k}\right]$ with negative values of $\delta t_{k}$. This means that the reference value is not reachable within $\mathrm{T}_{\mathrm{D}}$ duration; we need several command cycle. In this particular case, we choose the control value which drives the system the closest to its goal.

$\left(\right.$ Eq 7) $U_{M}:(X r e ́ f-X) \bullet \frac{d X}{d t}\left(U_{M}\right) \geq($ Xréf $-X) \bullet \frac{d X}{d t}\left(U_{k}\right), k=0$ à 3

One solves the above equation until one can get three different control values for a control cycle duration.

If state $X$ is on the line $D$, the $n$ all the four vectors $\frac{d X}{d t}(U k)$ are parallel and one can get a infinite set of solutions. We can then distinguish two different cases.

If capacitor voltage is close to its optimal value, one must keep this balance by applying the first and the last control value $\left(\mathrm{U}_{1}\right.$ and $\mathrm{U}_{3}$ ) during the same time. Time constraint is still taken into account so as to keep switching frequency constant and well-known. But only $\mathrm{Y}$-axis can be taken into account. Hence we solve equations (Eq 6) and (Eq 8) as well as (Eq 9) :
$(\mathrm{Eq} 8) \delta \mathrm{t}_{1} \frac{\mathrm{dis}}{\mathrm{dt}}\left(\mathrm{U}_{1}\right)+\delta \mathrm{t}_{\mathrm{is}} \frac{\mathrm{dis}}{\mathrm{dt}}\left(\mathrm{U}_{\mathrm{is}}\right)+\delta \mathrm{t}_{3} \frac{\mathrm{dis}}{\mathrm{dt}}\left(\mathrm{U}_{3}\right)=$ is réf $-\mathrm{is}_{\mathrm{s}}$

(Eq9) $\delta \mathrm{t} 1=\delta \mathrm{t} 3$

with the three following constraint : $\delta t_{1} \geq 0, \delta t_{i s} \geq 0, \delta t_{3} \geq 0$. If the capacitor voltage is far away from its reference value, no command value would be able to bring this voltage closer to its optimal value. As a matter of fact, the system cannot act upon capacitor voltage without an output current! In order to get closer to the good cell, one solve equation (Eq 7).

\section{E. Simulation results}

In this section, simulation results are presented for the following load converter parameters :

$$
\begin{gathered}
\mathrm{V}_{\mathrm{E}}=1500 \mathrm{~V}, \mathrm{C}=33 \mu \mathrm{F}, \mathrm{L}=5 \mathrm{mH}, \mathrm{R}=30 \Omega \text { and } \\
\mathrm{F}_{\text {Dréf }}=20 \mathrm{kHz} .
\end{gathered}
$$

Figure 4 illustrates static and dynamic behaviours of the proposed direct control law. Therefore, we choose a square cycle which means that we modify one state component after another. In the meantime, we let the system reach its steady state. The reference value commutate each $250 \mu$ s from $X_{k}$ to $\mathrm{X}_{\mathrm{k}+1}$ where $\mathrm{X}_{\mathrm{k}}$ are denoted as :

$\mathrm{X}_{0}=(700 \mathrm{~V} ; 45 \mathrm{~A}), \mathrm{X}_{1}=(700 \mathrm{~V} ; 35 \mathrm{~A}), \mathrm{X}_{2}=(800 \mathrm{~V}$; $35 \mathrm{~A})$ and $\mathrm{X}_{3}=(800 \mathrm{~V} ; 45 \mathrm{~A})$.

Commutation from $\mathrm{X}_{0}$ to $\mathrm{X}_{1}$ and from $\mathrm{X}_{2}$ to $\mathrm{X}_{3}$ illustrate normal behaviour. Commutation from $X_{1}$ to $X_{2}$ illustrates a reference value change due to, either an input voltage change $\mathrm{V}_{\mathrm{E}}$, or a new topology induced by a short circuit.
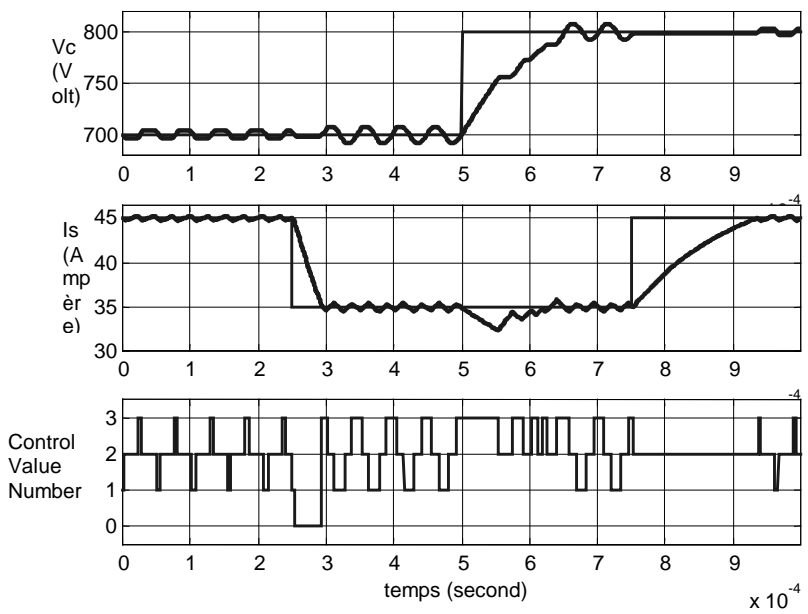

Input and state variable versus time

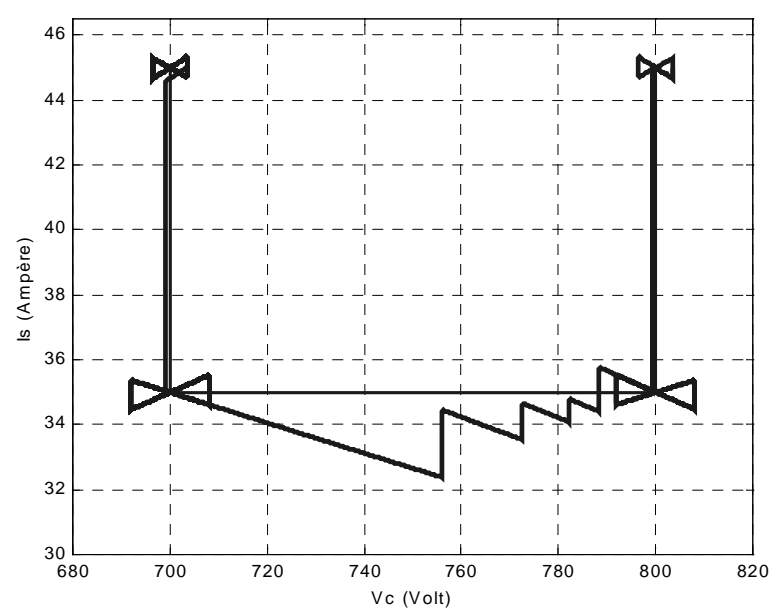

Phase Portrait

Figure $4:\left(i_{s}\right)_{\text {réf }}$ and $\left(v_{c}\right)_{\text {réf }}$ change at separated times Reference value $\leftrightarrow$ thin lines et state variables $\leftrightarrow$ thick lines 
Tracking the desired value $\left(i_{s}\right)_{\text {réf }}$ while $\left(v_{c}\right)_{\text {réf }}$ remains constant, the value of $\mathrm{v}_{\mathrm{c}}$ is perfectly controlled because there is always two control values allowing the system to go straight along $i_{s}-$ axis. On the other hand, a $\left(\mathrm{v}_{\mathrm{c}}\right)_{\text {réf }}$ change induces inevitably a disturbance on the $\left(i_{s}\right)_{\text {réf }}$ tracking because, except in particular case, all the values influence $v_{c}$ as well as $i_{s}$.

We note that in transient mode, the choice of the best command is constrained by a hysteresis criterion so as to avoid a high frequency chattering along the straight line delimiting the area where $U_{a}$ gives the best scalar product and the area where $\mathrm{U}_{\mathrm{b}}$ gives the best scalar product.

\section{STATE OBSERVER}

\section{A. Objective of the observer}

As we have already analysed, the previous direct control law leads to the best dynamic response allowed by this system while preserving the optimal limit cycles (harmonic and thermal properties). But, this algorithm requires, in real time, the value of the entire state. On the other hand a good knowledge of system parameter is essential. Whereas filter features (capacitance of the internal capacitor and inductance of the core in series with the load) are well-known because chosen, load resistor value is, by definition, unknown.

Moreover, to reduce drive cost and encumbrance we had better to measure only external variables: input voltage $V_{E}$ and output current $i_{\mathrm{s}}$.

These reflections lead us to design an extended state observer [5][6][7][14], load resistor value becomes the third component of the state vector. Assuming slow variation of this value, we write the following equation :

$$
\text { (Eq10) } \quad \frac{\mathrm{dR}}{\mathrm{dt}}=0 \text {. }
$$

The system to be observed is then described by the state equations :

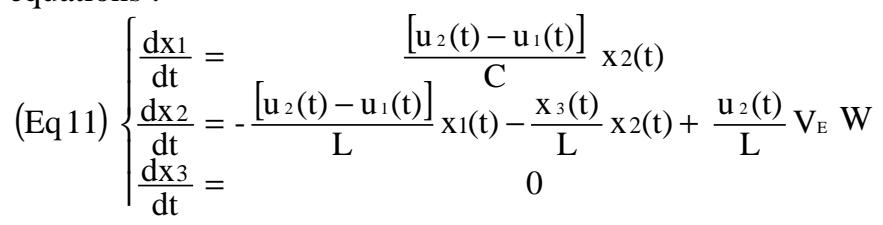

here, state is :

$$
\mathrm{X}=[\mathrm{vc} \text { is } \mathrm{R}]^{\mathrm{T}}
$$$$
\text { and both measures are } \quad \mathrm{y}=\mathrm{x}_{2} \text { and } \mathrm{z}=\mathrm{V}_{\mathrm{E}} \text {. }
$$

\section{B. Multi-cell chopper observer}

We have to check whether the knowledge of the control variable as well as the two measures and their derivatives allows us to reconstruct the extended state. For implementation reasons (noise susceptibility of the observer), we derivate only once the output variable.

As the system control variable is continuous step by step, we can get at each sequence :

$$
\text { (Eq10) }\left\{\begin{aligned}
\mathrm{y} & =\mathrm{dy} \\
\frac{\mathrm{d}}{\mathrm{dt}} & =-\frac{[\mathrm{u} 2-\mathrm{u} 1]}{\mathrm{L}} \mathrm{x} 1-\frac{\mathrm{x} 3}{\mathrm{~L}} \mathrm{y}+\frac{\mathrm{u} 2}{\mathrm{~L}} \mathrm{VE} \\
\frac{\mathrm{d}^{2} \mathrm{y}}{\mathrm{dt}^{2}} & =-\frac{[\mathrm{u} 2-\mathrm{u} 1]^{2}}{\mathrm{~L} \mathrm{C}} \mathrm{y}-\frac{\mathrm{x} 3}{\mathrm{~L}} \frac{\mathrm{dy}}{\mathrm{dt}}
\end{aligned}\right.
$$

In the particular case of a control variable such as $\left[\mathrm{u}_{2}-\mathrm{u}_{1}\right]=0$, $\mathrm{x}_{1}$ is not observable, which will even be true whatever the rank of derivates taken into account. For other cases, one can find $\mathrm{x}_{1}$ and $\mathrm{x}_{3}$ simultaneously $\left(\frac{\mathrm{dy}}{\mathrm{dt}}=0\right.$ is not persistent except for the duty cycle $1 / 2$ ).

\section{State observer design}

The state observer scheme is described by the following equation :

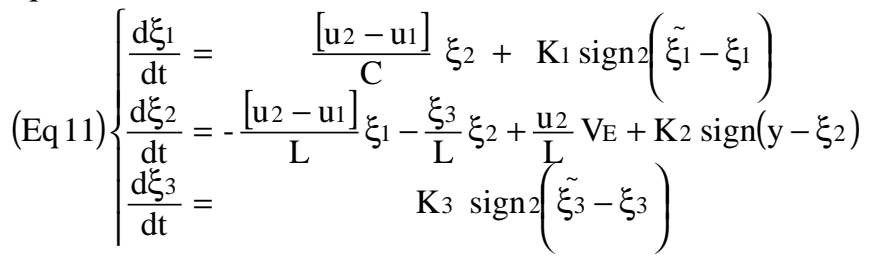

with :

$$
\begin{aligned}
& \tilde{\xi}_{1}=\xi_{1}-\frac{\mathrm{K}_{2} \times \mathrm{L}_{2}}{\left[\mathrm{u}_{2}-\mathrm{u}_{1}\right]} \operatorname{sign} 2, \operatorname{moy}\left(\mathrm{y}-\xi_{2}\right) \\
& \tilde{\xi_{3}}=\xi_{3}-\mathrm{K}_{2} \mathrm{~L}[1-|\mathrm{u} 2-\mathrm{u} 1|] \mathrm{y} \operatorname{sign} 2, \operatorname{moy}\left(\mathrm{y}-\xi_{2}\right)
\end{aligned}
$$

where the sign function $\operatorname{sign}_{2}$ is equal to since $\xi_{2}$ has not reached y.

The structure principle consist in observing the variable $\sigma=\left[\mathrm{u}_{2}-\mathrm{u}_{1}\right] \mathrm{x}_{1}+\mathrm{x}_{3} \mathrm{y}$ in finite state. To get the unknown couple $\left(\mathrm{x}_{1} ; \mathrm{x}_{3}\right)$, the chopper discrete behaviour into account. During the sequences where $\left[\mathrm{u}_{2}-\mathrm{u}_{1}\right]=0$, the knowledge of $\sigma$ gives exclusively the knowledge of $x_{3}$. During the sequences where $\left[u_{2}-u_{1}\right] \neq 0$, the knowledge of $\sigma$ gives the knowledge of $\mathrm{x} 1$ assuming that $\mathrm{x} 3$ dynamic is low next to the switching period.

Indeed, the observation error dynamic $\mathrm{E}=\mathrm{X}-\xi$ is given by:

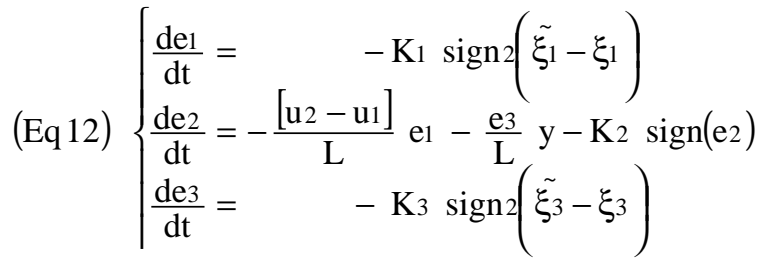

We demonstrate the observer convergence step by step [15] [16] :

During the first step, assuming

$$
\mathrm{K} 2=\left|\frac{\mathrm{VE}}{\mathrm{L}}\right|+\left|\frac{\mathrm{R} \text { MAX IMAX }}{\mathrm{L}}\right|+\varepsilon 2
$$

the observation error of the measured state component satisfies :

$$
\text { e2 } \frac{\mathrm{de}_{2}}{\mathrm{dt}} \leq-\left|\mathrm{e}_{2}\right| \varepsilon_{2}
$$

Hence, the estimated current $\xi_{2}$ converge in finite time towards the real measure $\mathrm{y}$; the convergence time is arbitrarily chosen by the means of the tuning parameter $\varepsilon_{2}$.

$$
\text { tconv } 2<\frac{\mathrm{e} 2(\mathrm{t}=0)}{\varepsilon 2}
$$

For $\mathrm{t}>\mathrm{t}$ conv $2, \mathrm{e}_{2}=0$, hence $\frac{\mathrm{de} 2}{\mathrm{dt}}=0$.

If the sequence with $\left[\mathrm{u}_{2}-\mathrm{u}_{1}\right]=0$ lasts long enough, $\xi_{3}$ converges towards $\mathrm{x}_{3}$. The observer is indeed on the sliding surface. Hence :

$$
\frac{\mathrm{de}_{2}}{\mathrm{dt}}=-\frac{\mathrm{e} 3 \mathrm{y}}{\mathrm{L}}-\mathrm{K}_{2} \operatorname{signéq}\left(\mathrm{e}_{2}\right)=0 \text {. }
$$

Which means the observation error dynamic of the third state component is given by : 


$$
\frac{\mathrm{de} 3}{\mathrm{dt}}=-\mathrm{K}_{3} \operatorname{sign}(\mathrm{e} 3) \text {. }
$$

The parameter $\mathrm{K}_{3}$ allows to choose the response time.

In the case of a persistent sequence such as $\left[u_{2}-u_{1}\right] \neq 0$, we also get $\tilde{\xi}_{1}=\mathrm{x} 1$ assuming $\xi_{3}$ has already converged towards $\mathrm{X}_{3}$. The observation error dynamic is then :

$$
\frac{\mathrm{de}_{1}}{\mathrm{dt}}=-\mathrm{K}_{1} \operatorname{sign}\left(\mathrm{e}_{1}\right)
$$

The tuning parameter K1 controls the convergence time.

\section{Simulation results}

In this section, we take the same features as before. The multicell chopper is in open loop controlled by a PWM modulator with a duty cycle $\alpha=3 / 4$.

The initial state is : $\mathrm{X}_{0}=\left[\begin{array}{c}\mathrm{vc} 0=750 \mathrm{~V} \\ \mathrm{is} 0=20 \mathrm{~A} \\ \mathrm{R} 0=30 \Omega\end{array}\right]$.

The observer is initialised with $\xi_{0}=\left[\begin{array}{l}\xi_{10}=0 \mathrm{~V} \\ \xi_{20}=0 \mathrm{~A} \\ \xi_{30}=0 \Omega\end{array}\right]$.

In the first simulation, the load resistor is increased linearly from $\mathrm{R}=30 \Omega$ to $\mathrm{R}=60 \Omega$. The estimated state $\xi$ (thin line) fits perfectly the real state $\mathrm{X}$ (thick line).
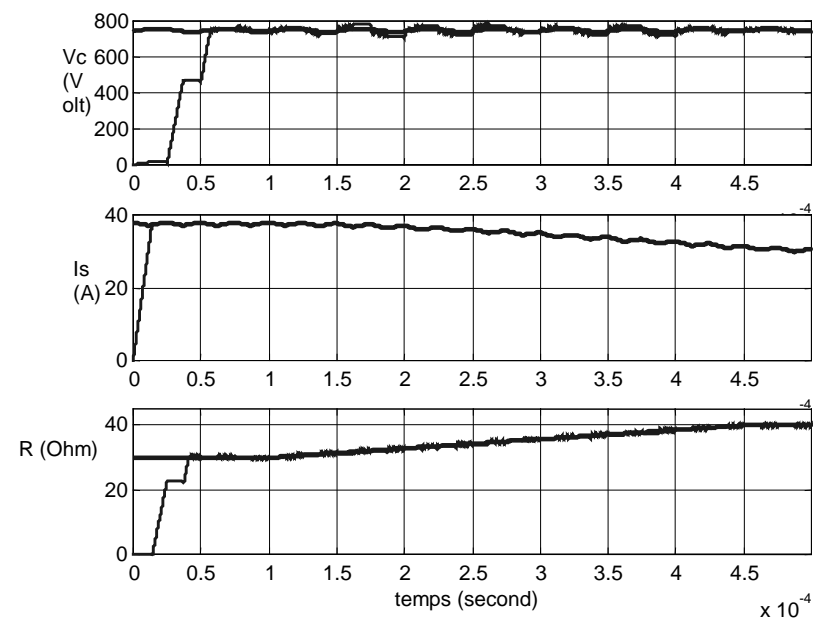

Figure 5: $\quad$ Extended state observer with "low dynamic" load

In the second simulation, the load resistor varies instantaneously from $\mathrm{R}=30 \Omega$ to $\mathrm{R}=60 \Omega$ at time $\mathrm{t}_{1}=150 \mu \mathrm{s}$ and from $\mathrm{R}=60 \Omega$ to $\mathrm{R}=30 \Omega$ at time $\mathrm{t}_{2}=310 \mu \mathrm{s}$. This behaviour does not fit our initial assumption of low dynamic load.

During the first transient sequence $(0 \mu \mathrm{s} \leq \mathrm{t} \leq 150 \mu \mathrm{s})$, as soon as the variable $\xi_{2}$ has reached the measured signal y, one notices an alternative convergence of $\xi_{1}$ towards $x_{1}$ and of $\xi_{3}$ towards $\mathrm{x}_{3}$ depending on the control variable value.

During the second transient sequence $(150 \mu \mathrm{s} \leq \mathrm{t} \leq 310 \mu \mathrm{s})$, the instantaneous change of $\mathrm{x}_{3}$ disturbs the estimated variable $\xi_{1}$. At particular time $\mathrm{t}=150 \mu \mathrm{s}$, the sequence is such as $\left[\mathrm{u}_{2}-\mathrm{u}_{1}\right] \neq 0$. So, the observer makes the mistake to modify the estimated variable $\xi_{1}$ according to the equivalent vector.

During the second transient sequence $(310 \mu \mathrm{s} \leq \mathrm{t} \leq 500 \mu \mathrm{s})$, the estimated variable $\xi_{1}$ is not disturbed by the quick change of $\mathrm{x} 3$ because it happens during the sequence such as $\left[\mathrm{u}_{2}-\right.$ $\left.\mathrm{u}_{1}\right]=0$.

This particular behaviour may become a real nuisance if this observer is used to detect a short circuit in a cell.
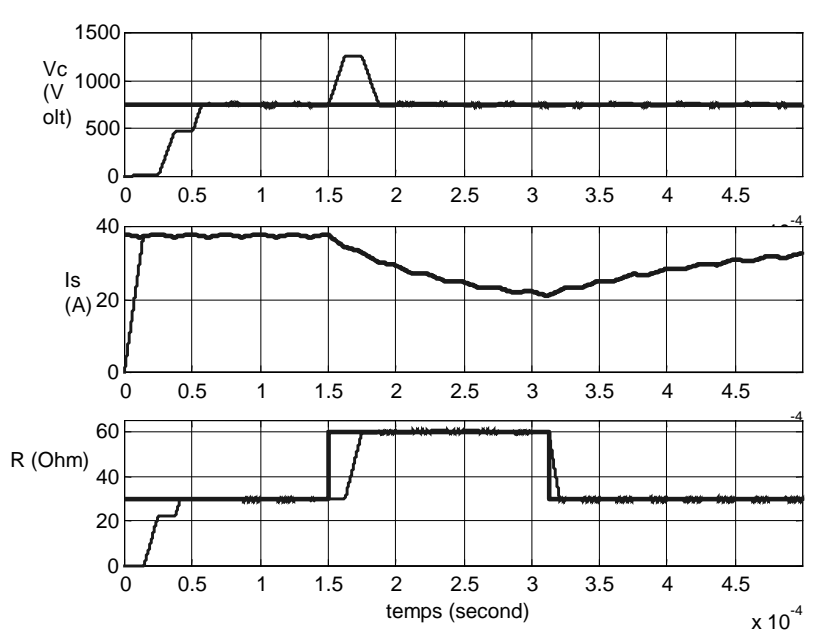

Figure 6: Extended state observer with "high dynamic" load

\section{CONTROL LAW AND STATE OBSERVER ASSOCIATION}

Our direct control law associated with our state observer yields very interesting results which underline advantages as well as drawbacks of our control scheme.

From a general point of view, the state observer has high dynamics performances. But, in steady state, the sign function leads to a small ripple around the tracked value. As the control law itself brings the best transient response we can expect from the system, this kind of feedback is particularly sensitive to high frequency noise. We can notice this feature in the basic association of the control law and the state observer (figure 7).

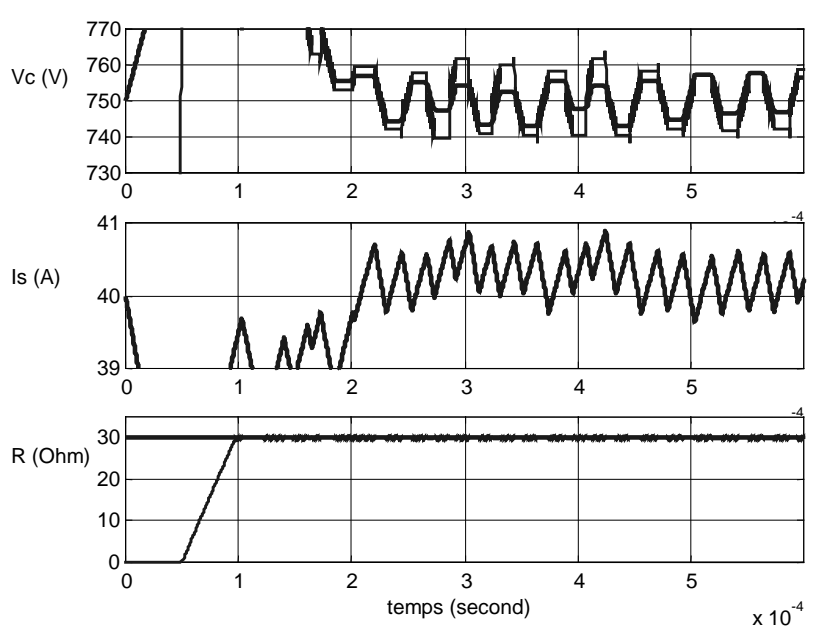

Figure 7 : Basic association the control law and the state sliding mode observer

(Constant current reference value $i_{\text {sréf }}=40 \mathrm{~A}$ )

If we substitute the arctangent function to the sign function, the state observer dynamic properties remain very good whereas the "chattering" phenomenon disappears. In this case, simulation results are the same as if $\mathrm{v}_{\mathrm{c}}, \mathrm{i}_{\mathrm{s}}$ and $\mathrm{R}$ measurements were perfect ! (Figure 8) 

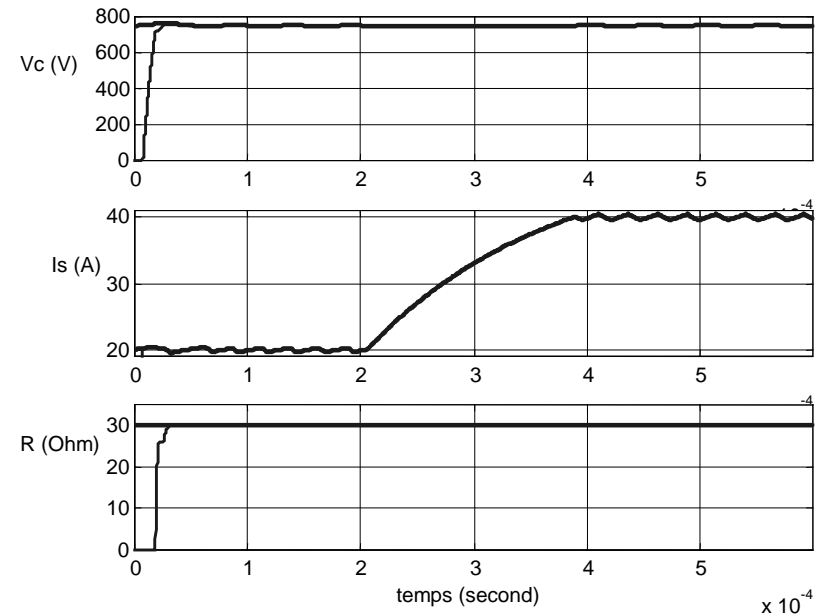

Figure 8: Direct control law with a modified sliding mode observer.

(Current reference value varies instantaneously at time $\left.\mathrm{t}_{1}=200 \mu \mathrm{s}\right)$

\section{CONCLUSION}

In this paper we designed, by a geometric approach, a direct control law (thus with fast transient response) which preserves, in steady state, the optimal multi-cell converter limit cycle. We then aimed to develop a sensorless control scheme of this converter. This objective leads us to synthesize a state observer robust to the most uncertain parameter (load resistor R). Control law and state observer association was also experimented. Simulation results confirm the effectiveness of this association even if they underline that state observer is the weak link of the chain.

As a matter of conclusion, this state observer should be very useful to detect and localize short circuit in cells. Figure 9 shows a simulation where a short circuit happens at time $\mathrm{t}=425 \mu$ s whereas the 2-cell chopper is in closed loop. The estimated voltage $x_{1}$ reaches very quickly the tracked voltage $\xi_{1}$ and the estimated load resistor $\xi_{3}$ remains perfectly constant as the real load resistor $\mathrm{x}_{3}$.
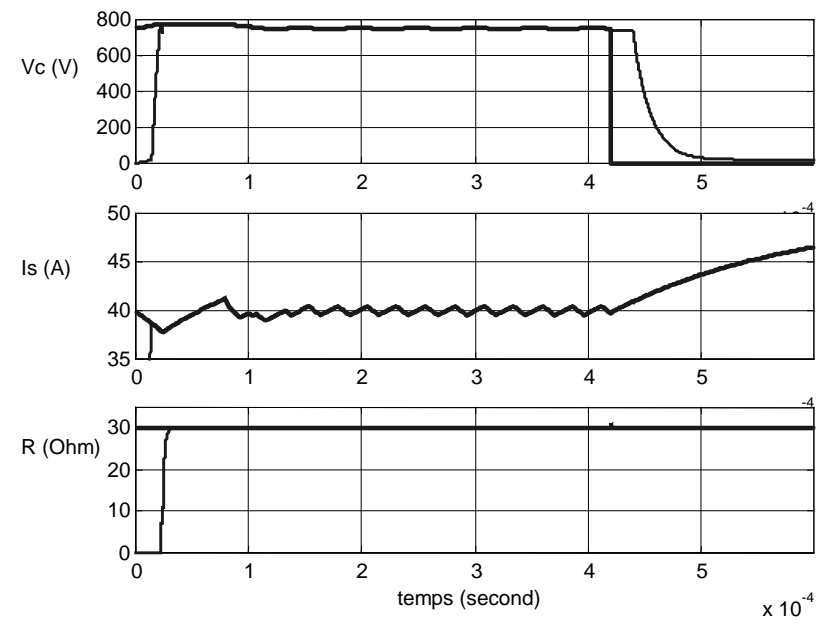

Figure 9 : Control law and state observer association Cell number one in short circuit

\section{REFERENCES}

[1] Th. Meynard et H. Foch : French patent $N^{\circ} 91,09582$ du 25 juillet 1991, dépôt international PCT (Europe, Japon, U.S.A., Canada) N 92,00652 du 8 juillet 1992

[2] $\mathrm{Ph}$. Carrère, «Etude et réalisation des convertisseurs multicellulaires à IGBT - Equilibrage des condensateurs flottants. » Ph. D. Thesis, Institut National Polytechnique de Toulouse, 1996.

[3] O. Tachon, M. Fadel et Th. Meynard, «Control of Series Multicells Converters by Linear State Feedback Decoupling. » EPE 97, Trondheim, pages 1-588 à 1-593, 1997.

[4] D. Pinon, M. Fadel et Th. Meynard, «Commande par mode glissant d'un hacheur à 2 cellules : étude de l'installation des cycles limites. » Revue Internationale de Génie Electrique, Volume 1 - n³/1998, pages 393 à 415.

[5] R. Bensaid, « Observateurs des tensions aux bornes des capacités flottantes pour les convertisseurs multicellulaires série. » Ph. D. Thesis, Institut National Polytechnique de Toulouse, avril 2001.

[6] R. Bensaid, M. Fadel, "Sliding Mode Observer for Multicell Converter», IFAC 2001 NOLCOS, Nonlinear Control Systems, Saint Petersbourg, Russie, juillet 2001.

[7] R. Bensaid, M. Fadel, « Floating voltages estimation in three-cells converters using discrete-time Kalman Filter », PESC 2001, Nonlinear Control Systems, juillet 2001.

[8] R. Bensaid, M. Fadel et Th. Meynard, «Observer design for a three-cell chopper using a discrete-time model », Electromotion, 2 : 689-694, juillet 1999.

[9] Ph. Beaudesson, «Sûreté de fonctionnement, reconfiguration et marches dégradées des onduleurs multiniveaux à IGBT. » Ph. D. Thesis, Institut National Polytechnique de Toulouse, octobre 2000.

[10] Ph. Beaudesson, F. Richardeau et Th. Meynard, «Sûreté de fonctionnement des convertisseurs statiques moyenne puissance - haute tension: tolérance aux défauts » Colloque National de Sûreté de Fonctionnement, Montpellier, France, Mars 2000, pp 579588.

[11] Ph. Beaudesson, F. Richardeau et Th. Meynard, «Caractérisation du convertisseur multicellulaire série en présence de défauts de commutation » Electronique de Puissance du Futur, Belfort, France, Décembre 1998, pp 129-134.

[12] A. Donzel et G. Bornard, « New Control Law for Capacitor Voltage Balance in Multilevel Inverter », IEEEIAS Conference, Rome, Italie, Octobre 2000.

[13] Aaron Sarinana Toledo, «Commande directe et Observation des Convertisseurs de Puissance : Application aux Onduleurs de Puissance triphasés Ph. D. Thesis, Laboratoire d'Automatique de Grenoble, France, Novembre 2000.

[14] G. Bornard, F. Celle-Couenne et G. Gilles, «Observabilité et Observateurs », «Systèmes Non Linéaires - Modélisation et Estimation », Chapitre 5, Masson, France, 1993.

[15] S. Drakunov, «Sliding Mode Observer based on Equivalent Control Method », IEEE CDC, Tucson, USA, 1992, pp 2368-2379.

[16] S. Drakunov et V. Utkin, «Sliding Mode Observer»,Tutorial in IEEE Conference.on Det. And Cont., 1995, pp 3376-3379 